\title{
United States - Sunset Reviews of Anti-Dumping Measures on Oil Country Tubular Goods from Argentina: a cloudy sunset
}

\author{
GENE M. GROSSMAN \\ Princeton University \\ JASPER WAUTERS \\ White and Case, LLP
}

\begin{abstract}
We review the WTO Appellate Body report on United States - Sunset Reviews of Anti-Dumping Measures on Oil Country Tubular Goods from Argentina (WT/DS268/AB/R, 29 November 2004). This dispute is one of several that deals with sunset reviews of antidumping-duty orders. In its ruling, the $A B$ reasserts a rigid distinction between mandatory and discretionary law, and sets a very high standard for Member challenges to laws or practices that allow for violations of WTO obligations but do not mandate such behavior. We argue that this ruling is unfortunate, because it diminishes scope of and incentives for 'as-such' challenges to laws and practices, which have a potentially useful role to play in the world trading system. The $\mathrm{AB}$ ruling also overlooks the purpose and objectives of sunset reviews - to ensure that duty orders are not extended when their removal would generate no harm to an import competing industry - by failing to impose sufficient discipline on their conduct. We argue that a sunset review requires an evaluation of competitive conditions in the industry and of the reasons and incentives for dumping, in order that the investigating authority can judge whether the removal of a duty order would lead to a continuation or recurrence of dumping and injury. The Appellate Body's rulings in this and other similar cases have the effect of relieving the investigating authority of this responsibility and thereby render the sunset review process virtually meaningless.
\end{abstract}

\section{The Dispute}

This dispute concerns the 'sunset' review conducted by the United States of an antidumping-duty order it had imposed on imports of oil country tubular goods

This paper reviews the WTO Appellate Body report United States - Sunset Reviews of Anti-Dumping Measures on Oil Country Tubular Goods from Argentina (WT/DS268/AB/R 29 November 2004). It is prepared for The American Law Institute project on the case law of the WTO. The views expressed are those of the authors and do not necessarily reflect the views of their respective employers. 
(OCTG) from Argentina and other sources. In a dumping investigation concluded in June 1995, the US Department of Commerce (USDOC) had found a dumping margin of $1.36 \%$ on exports by Siderca, the only Argentine exporter that had participated in its investigation. When the US International Trade Commission (USITC) found that dumped imports of OCTG from all sources had caused material injury to the domestic industry, the United States assessed an antidumping duty of $1.36 \%$ on all dumped imports of OCTG from Argentina. Siderca ceased to export OCTG to the United States following the application of that duty order.

In July 2000, five years after the order was issued, the USDOC initiated a so-called 'sunset review' to determine whether termination of the duty order on Argentine OCTG would likely lead to a recurrence or continuation of dumping, and the USITC investigated whether expiry of the duty order on all subject imports would likely lead to a continuation or recurrence of material injury to a US industry. When the investigating authorities found positively on both accounts and thus declined to revoke the duty order, Argentina complained to a disputesettlement panel that the United States had failed to fulfill certain of its obligations under the Agreement on Implementation of Article VI of the General Agreement on Tariffs and Trade 1994 (henceforth, the 'AD Agreement') by the manner in which it had conducted its sunset review.

Argentina's challenge included both claims against US laws and regulations 'as such' and against the application of such laws and regulations in the specific case of OCTG imports from Argentina. It argued before the Panel, inter alia, that Section II.A.3 of the US Sunset Policy Bulletin' (henceforth, the 'SPB') and USDOC 'practice' concerning determination of the likelihood of dumping in sunset reviews are inconsistent 'as such' with Article 11 of the AD Agreement governing the conduct of sunset reviews. Argentina also claimed that the USDOC had acted inconsistently with its obligations under various articles of the AD Agreement in the course of carrying out its sunset review of imports of OCTG from Argentina. In addition, it complained that the USITC had failed to obey the disciplines imposed by Articles 3 and 11 of the AD Agreement, which, it alleged, require an investigating authority to consider certain specific factors in the course of assessing the likelihood of recurrence or continuation of material injury. Moreover, it alleged impropriety in the US practice of cumulating imports from all subject sources in determining the likelihood of recurrence or continuation of injury. Of central importance in the case were Argentina's claims that certain provisions in Article 3 governing the determination of material injury in an initial dumping investigation also restrict the conduct of likelihood-of-injury investigations in sunset reviews.

1 'Policies Regarding the Conduct of Five-year ("Sunset") Review of Anti-dumping and Countervailing Duty Orders; Policy Bulletin’, United States Federal Register, 63(73) (April 16, 1998). 


\subsection{The SPB and USDOC practice on the likelihood of dumping}

Argentina pointed to Section II.A.3 of the SPB, which reads in relevant part as follows:

The Department normally will determine that revocation of an anti-dumping order or termination of a suspended dumping investigation is likely to lead to continuation or recurrence of dumping where -

(a) dumping continued at any level above de minimis after the issuance of the order or the suspension agreement, as applicable;

(b) imports of the subject merchandise ceased after issuance of the order or the suspension agreement, as applicable; or

(c) dumping was eliminated after the issuance of the order or the suspension agreement, as applicable, and import volumes for the subject merchandise declined significantly.

The Department recognizes that, in the context of a sunset review of a suspended investigation, the data relevant to the criteria under paragraphs (a) through (c), above, may not be conclusive with respect to likelihood. Therefore, the Department may be more likely to entertain good cause arguments under paragraph II.C in a sunset review of a suspended investigation.

Argentina maintained that the 'normal' practice described in Section II.A.3 of the SPB constitutes a mechanistic formula for sunset reviews, in contradistinction to the requirements of Article 11.3 of the AD Agreement that the authorities must 'determine, in a review ... that the expiry of the duty would be likely to lead to continuation or recurrence of dumping and injury'. Argentina noted that the WTO Appellate Body $(\mathrm{AB})$ had, in its ruling in US-Corrosion-Resistant Steel (para. 111), interpreted the words 'determine' and 'review' to 'suggest that authorities conducting a sunset review must act with an appropriate degree of diligence and arrive at a reasoned conclusion on the basis of information gathered as part of a process of reconsideration and examination'. A mechanistic practice could not fulfill this obligation. To bolster its case that the United States had failed to deliver the requisite 'diligence', Argentina provided evidence purporting to show that, in every sunset review previously undertaken by the USDOC, when the agency found that one of the three criteria outlined in Section II.A.3 had been satisfied, it had reached an affirmative finding of likely recurrence or continuation of dumping. Such a record, Argentina argued, could only result from a process in which the USDOC considers any of the three scenarios to be conclusive evidence of likely dumping. Therefore, the SPB and the consistent USDOC practices are not 'reasoned' but mechanistic, and accordingly should be ruled inconsistent with Article 11.3 of the AD Agreement.

The United States countered that, first, the SPB is not a 'measure' that can be challenged under the WTO dispute settlement process, and neither is it a government policy that has legal standing in US law. According to the United States, 
the SPB 'does not set forth rules or norms that are intended to have general prospective application'. Rather, it is meant 'simply as a transparency tool' to provide guidance to the public about evidence that normally would be considered probative. Inasmuch as the SPB does not require any particular process or finding by the USDOC in sunset reviews, the United States asserted, it cannot possibly breach any obligations under the $\mathrm{AD}$ Agreement, and so it should not rightfully be considered a subject for dispute settlement. In making these claims, the United States reiterated arguments it had put forth in US-Corrosion-Resistant Steel. The US argued that the USDOC sunset review practice cannot be challenged as a separate and independent measure under WTO law. Moreover, the United States added, even if the USDOC had never exercised its prerogative to rule negatively on the likelihood of continuation or recurrence of dumping in any case in which one of the three criteria of Section II.A.3 of SPB has been satisfied, that in no way would establish that it lacks the discretion to do so. The United States objected to a 'statistical analysis' that merely provides a 'correlation' between the scenarios set forth in Section II.A.3 and the outcomes of prior sunset reviews. According to the United States, Argentina had not fulfilled its obligation to prove that conformity with one of the three scenarios had determined the outcome of the sunset review of OCTG.

\subsection{Likelihood of injury and the original injury determination under Article 3}

A second main issue of dispute concerned the applicability of Article 3 of the AD Agreement, and in particular its mandates and tolerances for assessment of injury in an initial investigation of dumping to the procedures that could or must be used to assess the likelihood of continuation or recurrence of injury in the face of revocation of an antidumping-duty order.

Article 3 lays out the requirements for determining whether dumping has caused material injury to a domestic industry in the importing country. A footnote to the heading of Article 3 reads:

Under this Agreement the term 'injury' shall, unless otherwise specified, be taken to mean material injury to a domestic industry, threat of material injury to a domestic industry or material retardation of the establishment of such an industry and shall be interpreted in accordance with the provisions of this Article.

Argentina argued that the disciplines of Article 3 of the AD Agreement with respect to 'injury' apply also to determinations of likelihood of injury in sunset reviews. The United States, it claimed, had not made a determination of likely recurrence or continuation of injury that complied with the requirements of Article 3. In particular, Argentina argued that the USITC did not fulfill the country's obligations under the AD Agreement in its investigation of likely injury in the review of OCTG to the extent that it did not provide 'an objective examination of ... the volume of the dumped imports and the effect of the dumped 
imports on prices in the domestic market for like products, and ... the consequent impact of these imports on domestic producers of such products', that it did not provide 'evaluation of all relevant economic factors and indices having a bearing on the state of the industry' including the factors outlined in Article 3.4, and that it did not establish 'a causal relationship between the dumped imports and the injury to the domestic industry ... based on an examination of all relevant evidence' available to it.

Argentina offered two arguments for its interpretation of the Agreement as regards the applicability of Article 3 disciplines to the likelihood-of-injury investigation in a sunset review. First, it noted, Article 11.3 requires that a member undertake a 'review' of the need for continued imposition of antidumping duties to 'determine' that the expiration of the duties would likely lead to a continuation or recurrence of dumping and injury. The $\mathrm{AB}$ had interpreted Article 11.3 in US-Carbon Steel and US-Corrosion-Resistant Steel to mean that the sunset review must have sufficient factual basis to allow the investigating authority to draw a 'reasoned and adequate conclusion'. According to Argentina, Article 3 of the AD Agreement provides the details of what should be considered a sufficient factual basis for such a conclusion.

Second, Argentina pointed to the text of the footnote to the heading of Article 3. This footnote provides a definition of 'injury' that should apply throughout the agreement. Since the injury that is to be investigated in a sunset review, as required by Article 11, is the same as the injury defined in Article 3, the procedures for assessing the injury ought to be the same in both instances, and the disciplines of Article 3 ought to apply directly to sunset reviews.

\subsection{Cumulation in determination of injury in sunset review}

Argentina also questioned the legality of 'cumulation' in the assessment of likely injury in sunset reviews. Argentina considered that, contrary to the remainder of Article 3, subparagraph 3.3 of the AD dealing with cumulation, applies only to original investigations of dumping. Article 3.3 provides that where imports of a product from more than one country are simultaneously subject to antidumping investigations, the authorities may cumulatively assess the effects of all such imports. It further spells out the conditions under which an investigating authority may cumulate. However, Article 11.3 states that 'any definitive antidumping duty shall be terminated on a date not later than five years from its imposition ... unless the authorities determine ... that the expiry of the duty would be likely to lead to continuation or recurrence of dumping and injury'. Argentina argued that the use of the singular term 'duty' in Article 11.3 precludes the use of cumulation in sunset reviews, which instead must consider whether the expiry of a duty, as applied to imports from a single WTO Member, would be likely to lead to a continuation or recurrence of injury. A 'duty', according to Argentina, refers to a single order that applies to imports from one country. 


\subsection{The US response}

The United States refuted all of these claims. It pointed to the 'different nature' of original investigations and sunset reviews in asserting the different requirements for each. According to the United States, an original investigation must focus on extant conditions in the industry in order to assess the existence or threat of material injury. A sunset review, in contrast, necessitates a counterfactual analysis that addresses not the existing state of the industry, but the prospective state in the event of a removal of duties. Evidently, the different questions warrant different methods of analysis and consideration of different factors. Accordingly, the United States alleged, and notwithstanding the generally applicable definition of 'injury' in the footnote to the heading of Article 3, the disciplines imposed by that Article on initial investigations of injury cannot have been meant to apply also to sunset reviews.

Concerning the permissibility of cumulation in sunset reviews, the United States argued that the text does not speak to the issue and that 'Members are free to do that which is not prohibited.' The United States contested the significance given by Argentina to the singular use of the word 'duty' in Article 11.3, noting that the heading of Article 11 refers to 'duties' and that cumulation was a common practice by investigating authorities before the conclusion of the Uruguay Round, despite the use of the singular 'duty' in Article VI:6 of GATT 1994. Finally, the $\mathrm{AD}$ Agreement contains no cross-references that would link the prerequisites for the use of cumulation in an initial investigation, as outlined in Article 3.3, to obligations imposed by Article 11.3 for sunset reviews.

The parties disputed additional issues in this case having to do with the circumstances under which private parties are deemed to have waived their rights to participate in sunset reviews, the timeframe used by the USITC to assess the likelihood of recurrence of injury, and the appropriate standard for the term 'likely' in the matters considered in sunset reviews. However, we will limit our discussion in this paper to what we regard as the most important issues, which are the ones described above.

\section{The Panel report and the parties' appeals}

\subsection{The SPB - An Inconsistent Measure}

The Panel ruled that the SPB, indeed, is a measure that can be subject to WTO dispute settlement. It pointed for support to the AB report in US-CorrosionResistant Steel, which, it claimed, spoke directly to the issue. ${ }^{2}$ The United States challenged this ruling on appeal, claiming that the AB's reversal of the Panel's ruling in the earlier case had been based on the insufficiency of the Panel's analysis.

\footnotetext{
2 The Panel referred to the AB's statement in para. 81 of US-Corrosion-Resistant Steel that ' any act or omission attributable to a WTO Member can be a measure of that Member for purposes of dispute settlement proceedings'.
} 
Inasmuch as the $\mathrm{AB}$ did not go on to complete or correct the Panel's analysis in US-Corrosion-Resistant Steel, it did not intend to resolve the issue of whether the SPB can be the subject of a WTO complaint. The United States reiterated its position on appeal that the SPB has no legal standing in US law and that it is only a tool to provide information to the private sector. The United States argued that the Panel had neglected the status of the SPB within the municipal system of the country.

On the consistency of the SPB, as such, with Article 11.3 of the AD Agreement, the Panel also ruled in favor of Argentina. It observed that the AB had ruled out mechanistic or formulaic approaches to sunset review in US-Corrosion-Resistant Steel, and stated that, as a result, any scheme that attributes 'determinative value' to certain factors - as opposed to indicative value-is 'likely to violate' Article 11.3 of the AD Agreement. ${ }^{3}$ The Panel reasoned that if any of the three scenarios in Article II.A.3 of the SPB is treated as conclusive for determining the likelihood of continuation or recurrence of dumping, then the SPB must be deemed inconsistent with Article 11.3. The Panel first examined whether the text of the SPB and the three scenarios set forth therein are meant to be 'determinative' or simply 'indicative' and concluded that the wording was ambiguous on this point. It thus proceeded to examine how the SPB had been applied in practice. The Panel concluded from the evidence provided by Argentina that the USDOC does indeed regard the provisions of Section II.A.3 of the SPB to be determinative regarding the likelihood of continuation or recurrence of dumping subsequent to the expiry of an antidumping-duty order. Thus, it ruled the SPB to be inconsistent with US obligations under the AD Agreement.

The United States challenged this ruling as well, claiming that the Panel's finding was based on a mere statistical analysis of prior sunset reviews and thus did not meet the standard for an 'objective assessment' in the current case. It reiterated that the USDOC has discretion to come to any conclusion it deems warranted about the likelihood of continued or recurring dumping, notwithstanding the correspondence of the facts in a case with the scenarios in Article II.A.3 and notwithstanding the pattern of findings in its prior reviews. The fact that the USDOC has not, as yet, exercised its discretion to deviate from the scenarios set forth in the SPB does not change the fact that it has such discretion. In sum, the Panel had failed to show that the text of Article II.A.3 of the SPB had caused the positive determination in the OCTG sunset review.

\subsection{Article 3 disciplines not applicable to sunset reviews}

In considering the applicability of the disciplines of Article 3 to sunset reviews, the Panel observed that in US-Corrosion-Resistant Steel, the AB had noted the differences between initial investigations and sunset reviews and had ruled that the investigating authority is not obliged to make a determination of existing dumping

3 WT/DS268/R (hereinafter, the 'Panel Report'), para. 7.143. 
in a sunset review. By analogy, the Panel reasoned, it should not be obliged to make a determination of existing injury. Inasmuch as the authority is under no obligation to rule on existing injury (but only the likelihood thereof subsequent to a removal of duties), it need not follow the dictates of Article 3. However, the Panel ruled that if the authority does, indeed, undertake to determine the presence of injury in a sunset review, or relies on a past-injury determination in its sunset review, it would be bound to do so in the manner set out in Article $3 .^{4}$

Argentina appealed this ruling, submitting that a rigorous and detailed examination of the issue of likely injury is mandated by the terms 'review' and 'determine' in Article 11.3. These words impose substantive disciplines on the conduct of an injury determination in any dumping investigation. Article 3 spells out what the Members considered to be necessary for such an examination. Therefore, Argentina claimed, these disciplines were meant to apply in sunset reviews as well. Argentina reiterated its claim that the footnote to the heading of Article 3 imposes a uniform definition of injury for the entirety of the AD Agreement, and that, by implication, any reference to injury in the Agreement must be interpreted in accordance with the provisions outlined in the remainder of Article 3. The investigating authority in a sunset review could not determine the likelihood of continuation or recurrence of injury following the removal of an antidumpingduty order unless it followed the steps outlined in Article 3, where 'injury' is defined and discussed.

\subsection{Cumulation permitted in sunset reviews without disciplines imposed by Article 3.3}

The Panel also ruled against Argentina on the permissibility of cumulation in sunset reviews. The Panel regarded the lack of an explicit statement in the Agreement as to whether cumulation is generally permitted to imply that investigating authorities are not prohibited from choosing this approach. It rejected Argentina's argument based on the use of the singular term 'duty' in Article 11.3, finding this attribution of 'far-reaching substantive meaning' to the use of the singular rather than the plural to be 'implausible'. ${ }^{5}$ The silence of Article 11.3 on the question of cumulation was considered to imply a permission to cumulate also at the review stage. The Panel emphatically rejected Argentina's argument that, if cumulation is allowed in a sunset review, then surely the disciplines set forth in Article 3.3 for original investigations would apply at this stage as well. The Panel ruled that Article 3.3 governing the use of cumulation in initial investigations of dumping does not apply to sunset reviews, because Article 3.3 expressly mentions that the conditions are meant to govern investigations of the effects of existing dumping. ${ }^{6}$ The Panel held that the text of Article 3.3 thus clearly

4 Panel Report, para. 7.274.

5 Ibid., para. 7.334 .

6 Ibid., para. 7.336 . 
limits its applicability to original investigations. Argentina challenged these findings on grounds similar to its original arguments to the Panel. It claimed that the use of the singular term 'duty' was purposive, reflecting the Members' recognition that the changed circumstances over five years of application of a duty order, and the prospective nature of the likelihood inquiry, would render an investigating authority incapable of assessing the appropriateness of cumulation in a sunset review. For example, imports from a particular Member might no longer be present in the market, as was the case for imports of OCTG from Argentina. According to Argentina, the lack of a factual basis for assessing the appropriateness of cumulation explains why the authorization in Article 3.3 was meant to be limited to initial investigations. In any case, if cumulation is deemed to be permissible in sunset reviews, some constraints on its use such as those outlined in Article 3.3 certainly are implied, or else the investigating authorities would be free to use cumulation without discipline, which could not have been the Members' intended outcome.

\section{The Appellate Body's decision}

\subsection{The SPB - a measure, but is it inconsistent?}

The AB upheld the Panel's ruling that the SPB is a 'measure' subject to WTO dispute settlement. It regarded the United States's argument that the SPB is not a legal instrument under US law as irrelevant to whether it is a measure that can be challenged in the WTO, because the WTO dispute settlement bodies have no standing to opine on matters of US domestic law. Rather, the dispute settlement bodies must judge what policies are consistent with the provisions of the WTO Agreement and, for that purpose, they must consider 'acts setting forth rules or norms intended to have general and prospective application' as falling within their purview. The $\mathrm{AB}$ found that the SPB is a measure that can be subject to dispute settlement, because it has 'normative value' inasmuch as it 'provides administrative guidance and creates expectations among the public and among private actors'. Moreover, it is intended to have 'general' and 'prospective' application, because it is meant to apply to all sunset reviews conducted by the United States (para. 187).

However, the AB reversed the Panel's finding that Section II.A.3 of SPB is inconsistent, as such, with Article 11.3 of the AD Agreement. The AB endorsed the Panel's standard for assessing the consistency of the SPB with Article 11.3, namely that consistency hinged on whether the three scenarios of Section II.A.3 are determinative or merely indicative in the analysis of continued or recurring dumping. It also concurred with the Panel that the text of SPB is not dispositive of the question whether the three scenarios set out in the SPB should be regarded by the USDOC as conclusive. However, it differed with the Panel on the significance of the historical data provided by Argentina regarding the outcomes of prior sunset reviews. 
First, the $\mathrm{AB}$ observed that the 'volume of dumped imports' and 'dumping margins' before and after the issuance of antidumping-duty orders are highly important factors in evaluating the likelihood of continuation or recurrence of dumping. Therefore, the scenarios described in Section II.A.3 of SPB have probative value. In the view of the $\mathrm{AB}$, in order to determine whether the scenarios are regarded by the USDOC as conclusive, the Panel would have had to identify cases in which the conditions of one of the scenarios were met, and yet the probative value of other factors would have outweighed that of the relevant scenario and would have led to a different finding. In this instance, the Panel did not look for or identify such examples, but relied solely on the 'correlation' provided by Argentina. Since the Panel did not undertake a qualitative analysis of any of the cases included in the aggregate statistics, it could not know whether the determinations rested on factual foundations or whether they had been reached mechanistically. The $A B$ concluded that, without qualitative examination of any of the cases underlying the aggregate statistics submitted by Argentina, it is 'not possible to conclude definitively that these determinations were based exclusively on these scenarios in disregard of other factors' (para. 212, emphasis added). The AB regretted that the United States had failed to identify cases in which other factors constituted the basis for the USDOC's determination or where the probative value of the scenarios outweighed that of other factors introduced by interested parties. In short, the United States had not challenged the factual correctness of Argentina's statistics, nor had it provided any evidence to counter the proposition that the USDOC applied the three scenarios in a mechanistic fashion. However, the AB considered that the lack of such assistance from the United States cannot excuse the Panel from conducting an objective assessment of the matter (para. 214). Finally, the AB emphasized that its ruling should not be taken to hold that Section II.A.3 of the SPB is in fact consistent with Article 11.3 of the AD Agreement, but only that the Panel had failed to meet the standards required for it to find a violation of the agreement.

\subsection{Article 3 injury disciplines do not apply in sunset reviews}

The AB upheld the Panel's decision that the investigating authorities are not bound to consider all of the specific factors mentioned in Article 3 of the AD when determining the likelihood of injury in a sunset review. The AB accepted Argentina's claim that the footnote to the heading of Article 3 defines 'injury' for the whole of the $\mathrm{AD}$ Agreement, but rejected its argument that the designation of a single definition implies that all provisions of Article 3 concerning the determination of injury in original investigations apply also to sunset reviews. According to the $\mathrm{AB}$, a distinction can be made between the definition of injury and the determination of injury (para. 277). The Agreement further distinguishes between a determination of injury, addressed in Article 3, and a determination of likely recurrence or continuation of injury, addressed in 
Article 11.3. These two determinations are different in nature and have different purposes, according to the AB (para. 279). Article 11.3 contains neither a crossreference to Article 3 nor a textual basis for concluding that any of the specific provisions in Article 3 must be followed by the investigating authorities in a sunset review. While the words 'review' and 'determine' in Article 11.3 do require 'a reasoned conclusion on the basis of information gathered as part of a process of reconsideration and examination' (para. 283), they leave room for the investigating authority to design and implement an appropriate analysis that fulfills this obligation. In other words, such a requirement does not have to be satisfied through a specific methodology or the consideration of particular factors in every case, such as those mandated by Article 3 in the case of original determinations. Nevertheless, certain of the analyses mandated by Article 3 may prove to be probative or even required in order for an authority to arrive at a reasoned conclusion. For example, the $\mathrm{AB}$ considered that the fundamental requirements of 'positive evidence' and an 'objective examination' of Article 3.1 would be equally relevant to likelihood determinations under Article 11.3 (para. 284).

\subsection{Cumulation in sunset reviews - a permissible practice without disciplines?}

Finally, the AB upheld the Panel's ruling that Article 11.3 does not prohibit the use of cumulation in the likelihood-of-injury determination of a sunset review, nor do the conditions of Article 3.3 for the use of cumulation in an initial investigation necessarily apply to a sunset review. The AB rejected Argentina's argument about the significance of the use of the singular term 'duty', because the agreement uses the singular term also in other places (such as in Article 9.2) to apply to circumstances in which there are multiple sources of a dumped product from one or several countries. The mere use of the term 'duty' in the singular in Article 11.3 does not necessarily suggest that the likelihood-of-injury determination must be made on a Member by Member basis (para. 293). In addition to this textual argument, the $\mathrm{AB}$ observed that the rationale for allowing cumulation in original investigations is 'equally applicable' to likelihood-of-injury determinations. When considering the likelihood of continuation or recurrence of injury, the prospective injury in question might be caused by imports from multiple sources at the same time, just as the extant injury in an initial investigation might have multiple sources. Therefore, the reasons why cumulation might be potentially useful in evaluating the cause of existing injury are also reasons why it might be useful in evaluating the likelihood of future injury upon the expiry of an antidumping-duty order. The AB concluded that given the expressed intent of the Members to permit cumulation in injury determinations in the initial investigation and the rationale that exists for doing so, which applies also to the determination of the likelihood of future injury, the Members did not mean to preclude the use of cumulation in sunset 
reviews. ${ }^{7}$ Nor did the $\mathrm{AB}$ accept Argentina's arguments that, if cumulation is permissible in sunset reviews, it must meet the conditions specified in Article 3.3 for initial investigations, or else there would be no discipline at all on such reviews. According to the $\mathrm{AB}$, the text of Article 3.3 limits its applicability to original investigations. This does not imply that the authorities have carte blanche when deciding to cumulate, because sunset reviews must be based on a 'rigorous examination' leading to a 'reasoned conclusion' supported by 'positive evidence' and a 'sufficient factual basis' (para. 302). These requirements also govern the decision to resort to cumulation and thus impose substantive disciplines on the authorities.

\section{Legal analysis}

\subsection{The SPB: 'measures' in the WTO}

For a proper understanding of the issue, it is perhaps useful to recall the origins of the Sunset Policy Bulletin and its relationship to other instruments of US law. The United States did not have any sunset provision for its antidumping duties prior to the conclusion of the Uruguay Round and the introduction of the Uruguay Round Agreements Act. ${ }^{8}$ Sections 751 (c) and 752 to the Tariff Act, which were added to US law following the conclusion of the Agreement, provide for such reviews. Amendments to the Regulations further implemented the new regime. ${ }^{9}$ Section 218 of Part 351 of Title 19 of the Regulations lays out the specific rules that the USDOC must follow when conducting a sunset review.

Before the United States began its first sunset review, the USDOC published the Sunset Policy Bulletin in the US Federal Register. In the Sunset Policy Bulletin, the agency sets forth 'policies regarding the conduct of five-year ('sunset') reviews ... pursuant to the provisions of sections 751 (c) and 752 of the Tariff Act of 1930, as amended, and [USDOC's] regulations'. ${ }^{10}$ The Sunset Policy Bulletin is 'intended to complement the applicable statutory and regulatory provisions by providing guidance on methodological or analytical issues not explicitly addressed by the statute and regulations'.11

The question before the Panel and the AB in this case was whether such a 'policy document' can actually be challenged 'as such' before the WTO, i.e. independent

\footnotetext{
7 Since sunset reviews are to be based on existing facts, as well as projected events, the AB rejected Argentina's argument that cumulation in sunset reviews would not be appropriate for lack of a 'factual basis' (AB Report, para. 299).

8 Uruguay Round Agreements Act, Public Law 103-465, 108 Stat. 4809, which became law in the United States on 8 December 1994.

9 'Procedures for Conducting Five-Year ("Sunset") Reviews of Anti-dumping and Countervailing Duty Orders', United States Federal Register, 63(54)(20 March 1998), p. 13516, codified in Part 351 of Title 19 of the Regulations.
}

10 SPB, p. 18871.

11 SPB, pp. 18871-18872. 
of its application in a particular case, and independent of the statute and regulations it is intended to complement. In prior cases, the $A B$ had expressed the view, which was reiterated in this case, that, in principle, any act or omission attributable to a WTO Member can be a measure for purposes of dispute settlement proceedings. The acts or omissions that are so attributable are, typically, acts or omissions of the organs of the state, including those of the executive branch. ${ }^{12}$ This clearly means that even nonbinding administrative guidance may be subject to challenge as a 'measure'. ${ }^{13}$ The Panel relied on past statements of the AB in ruling that the SPB is a measure subject to dispute settlement and the AB logically upheld that decision.

In light of its previous rulings that 'anything goes', it is perhaps surprising that the AB felt it necessary to justify its ruling that the SPB is a measure that can be subject to dispute settlement on the basis that "it has "normative value" and is intended to have "general" and "prospective" application' (para. 187). If any act or omission attributable to the state can be challenged before the WTO, why should it matter that the SPB has normative value or that it is intended to have general and prospective application?

In our view, the issue of what constitutes a measure is much ado about nothing. Questions such as those that were addressed in this case confuse form with substance. Any act or omission attributable to a state is capable of engaging state responsibility, regardless of the form in which the act is expressed. This surely implies that a series of acts that reveal a practice may be challenged as well. Strangely, the AB has repeatedly stated - including in this case - that it has yet to pronounce on the issue of whether a practice may be challenged 'as such' in WTO dispute settlement. ${ }^{14}$ Yet, at the same time, it considers the SPB, which is nothing more than the codification and documentation of an intended practice, to be a measure that can be challenged.

Indeed, the SPB is not a law or regulation. Rather, it announces the intentions of a governmental agency and explains how the agency will use the discretion

12 US-Corrosion-Resistant Steel, para. 82; also see AB Report, Guatemala-Cement I (footnote 47 to para. 69), where the AB ruled that in the practice established under the GATT 1947, a 'measure' may be any act of a Member, whether or not legally binding, and it can include even nonbinding administrative guidance by a government.

13 This view was based on the practice established under the GATT 1947 confirming that a measure may be any act of a Member, whether or not legally binding, and it can include even nonbinding administrative guidance by a government (see Japan-Trade in Semi-Conductors, adopted 4 May 1988, BISD 35S/116). It is clear that a measure can also be an omission or a failure to act on the part of a Member (see, for example, India-Patent Protection for Pharmaceutical and Agricultural Chemical Products, complaint by the United States, WT/DS50/R and WT/DS50/AB/R, adopted 16 January 1998, and also India - Patent Protection for Pharmaceutical and Agricultural Chemical Products, complaint by the European Communities and its Member States, WT/DS79/R, adopted 22 September 1998).

14 In para. 220, the AB wrote, 'Therefore, even assuming arguendo that a practice may be challenged as a measure in WTO dispute settlement - an issue on which we express no view here.' In US-Gambling, the $\mathrm{AB}$ stated that it 'has not, to date, pronounced upon the issue of whether " practice" may be challenged as such, as a measure in WTO dispute settlement' (para. 132). 
left to it by the applicable legal instruments. A 'practice' may be regarded either as a string of individual cases or as a norm not expressed in a formal government document, or both. But is there any real difference between an unwritten norm and a written document such as the SPB? The expression of the norm in written form does facilitate the job of the complaining party, who can then point to the document to establish that a norm exists. When no such documentation of a practice is available, the complaining party may face a greater evidentiary burden in establishing the meaning and scope of the norm. But, in either case, there should be no difference for implementation purposes between a challenge to practice and a challenge to a particular instance in which the practice is used. When a practice is successfully challenged, the Member engaging in that practice must change its behavior and amend any written codification thereof. When a Member is found to have violated its obligations in a particular case, its good-faith implementation of the settlement ruling requires similarly that it change its behavior in any comparable situations that might subsequently arise. In other words, a Member that violates a WTO Agreement in some instance is obliged not only to right the wrong, but to change its practice as well.

So, why would a Member challenge a practice, when the evidentiary burden is greater in such a case and a successful challenge of a particular application ought to yield the same outcome? And why must the system tolerate such challenges to practice? The answers have to do with the realities of implementation. The recent disputes over US practice of 'zeroing' in calculating dumping margins are a case in point. In these disputes, the EC and Japan challenged the US practice of zeroing as such-in US-Zeroing (EC) and US-Zeroing (Japan)-presumably because they were not convinced that a ruling against zeroing in a particular instance would suffice to induce the United States to amend its general practice. ${ }^{15}$ Given the persistence of US practice on this matter, their concerns apparently were warranted. And precisely because of this possibility for recalcitrant implementation, it is important that Members be allowed to challenge any measure, be it a law, a regulation, or a practice, and be it in written form or not.

In short, we believe that the AB was correct to consider the SPB to be a measure subject to dispute resolution, but not because it has normative value and is intended to have general and prospective application. Rather, the conclusion is warranted by the fact that the SPB represents an act of the US government that outlines its intended practice in sunset reviews.

15 In contrast, India challenged a similar zeroing practice by the EC in EC-Bed Linen, but in this case the challenge was made to a particular instance in which the practice was used, namely in the alleged dumping of bed linen. When the EC's method of calculating the dumping margin was found to be in violation of the $\mathrm{AD}$ Agreement in the bed-linen case, the EC proceeded to change its methodology for calculating dumping margins for all subsequent investigations. 


\subsection{When does a nonbinding instrument or a 'practice' violate WTO obligations?}

The $\mathrm{AB}$ rulings on the SPB are important from a systemic point of view. In our opinion, they represent an unfortunate return to a strict application of the GATT distinction between mandatory and discretionary law. Hopes were raised following the Appellate Body's report in US-Corrosion-Resistant Steel that the end of this strict distinction was near. It appeared that the $\mathrm{AB}$ would be willing to accept that not only legislation requiring WTO-inconsistent behavior, but also laws that allowed such behavior could be found to violate a Member's obligations under the Agreement. Support for a less rigid interpretation of the old GATT distinction had been aptly expressed by the Panel in US-Section 301. We fear that the ruling in US-OCTG from Argentina closes the door once more and reveals the AB's intention to maintain a strict interpretation of the distinction. Evidently, the $A B$ will consider only laws, regulations, and administrative measures that mandate WTO-inconsistent action to be in possible violation of a Member's obligations.

We recall that under general public international law, a State may challenge the particular application of a law or regulation, but State responsibility is not engaged by the mere existence of a law. ${ }^{16}$ The situation is different in the GATT/WTO where the GATT Contracting Parties and WTO Members are allowed to challenge another Member's laws or regulations independent of their application in a particular case. The international trading system was structured this way, because the provisions of the GATT/WTO are meant not only to protect current trade but also to create a predictable environment for future trade. If Members could not challenge legislation that mandates actions at variance with the Agreement until the administrative acts implementing the legislation had actually been applied to their trade, the worthy objective of predictability would be defeated. ${ }^{17}$

Traditionally, however, the opportunity to challenge legislation on an 'as such' basis has been limited to legislation that mandates actions inconsistent with

16 This point was noted by the Panel in US-Section 301:

Under traditional public international law, legislation under which an eventual violation could, or even would, subsequently take place, does not normally in and of itself engage State responsibility. If, say, a State undertakes not to expropriate property of foreign nationals without appropriate compensation, its State responsibility would normally be engaged only at the moment foreign property had actually been expropriated in a given instance. (para. 7.80).

17 GATT Panel Report, United States-Superfund, para. 5.2.2, referred to by the AB in US-1916 Act, para. 88. The Panel in US-Section 301 also pointed to the indirect impact of trade laws on individuals as being the main difference between public international law and international trade law in order to explain this different approach to challenging legislation on an 'as such' basis:

In treaties which concern only the relations between States, State responsibility is incurred only when an actual violation takes place. By contrast, in a treaty the benefits of which depend in part on the activity of individual operators the legislation itself may be construed as a breach, since the mere existence of legislation could have an appreciable 'chilling effect' on the economic activities of individuals. (para. 7.81) 
the Agreement. Under this approach, only laws, regulations, and administrative measures that require behavior inconsistent with the trade agreement or that impede a country's compliance with its obligations under the agreement may constitute a violation as such. If a law leaves the administrative authorities with the discretion to act in a manner inconsistent with WTO obligations, such a law would not be considered in violation 'as such' with the Agreement. Rather, Members would need to challenge specific applications of such laws and show that the discretion left to the administrative authorities had been exercised in a manner that constituted a violation. The $\mathrm{AB}$ applied this distinction in a number of cases, most conspicuously in its report on US-1916 Act..$^{18}$

Nevertheless, and surprisingly, the $\mathrm{AB}$ stated in its report on US-CorrosionResistant Steel that it had yet to make any determination as to the continued validity of this distinction in WTO law. In that case, which was the first to challenge the SPB, the AB overturned the Panel's decision for having applied the distinction between mandatory and discretionary law in a 'mechanistic fashion'. It considered the distinction to be an analytical tool, the importance of which would vary from case to case. ${ }^{19}$

The decision in US-Corrosion-Resistant Steel was hailed by some as an important reversal in the AB's approach. Howse and Staiger (2006: 34) conclude that 'by placing such emphasis on the status of the mandatory/discretionary distinction as an "analytical tool", the $\mathrm{AB}$ is telling us what the distinction is not: it is not a meta-rule that overrides or precludes the determination of state responsibility based on a reading of WTO treaty provisions.' They interpreted the $\mathrm{AB}$ as saying that a discretionary law could now be found to violate a Member's obligations under the WTO Agreement. In so doing, they suggested that the AB's arguments appeared to echo those of the Panel in US-Section 301 and that the AB seemed to be endorsing, albeit implicitly, the jurisprudence of that Panel.

We recall that the Panel in US-Section 301 made a convincing case for allowing discretionary legislation to be successfully challenged under certain circumstances. In that case, the Panel ruled that the traditional dichotomy between mandatory and discretionary law did not imply that discretionary legislation could never violate a WTO Agreement. Rather, the potential for discretionary legislation to contravene the Agreement would depend on the type of obligation that allegedly had been violated. For example, if the Agreement obliges a certain behavior, and thereby excludes administrative discretion, a law that allows such discretion presumably would constitute a violation of obligations. ${ }^{20}$ The Panel gave the following instructive illustration to clarify its point:

Imagine two farmers with adjacent land and a history of many disputes concerning real and alleged mutual trespassing. In the past, self help through force

18 AB Report, US-1916 Act, paras. 87-88.

19 AB Report, US-Corrosion Resistant Steel, para. 93.

20 Panel Report, US-Section 301, para. 7.54. 
and threats of force has been used in their altercations. Naturally, exploitation of the lands close to the boundaries suffers since it is viewed as dangerous terrain. They now sign an agreement under which they undertake that henceforth in any case of alleged trespassing they will abjure self help and always and exclusively make recourse to the police and the courts of law. They specifically undertake never to use force when dealing with alleged trespass. After the entry into force of their agreement one of the farmers erects a large sign on the contested boundary: 'No Trespassing. Trespassers may be shot on sight.'

One could, of course, argue that since the sign does not say that trespassers will be shot, the obligations of the agreement have not been violated. But would that be the 'better faith' interpretation of what had been promised? Had they not pledged always and exclusively to make recourse to the police and the courts of law? (paras. 7.65-7.66)

We concur with the sentiment expressed by the Panel in US-Section 301. The potential for a discretionary law to be inconsistent with a WTO Agreement should vary with the type and nature of the obligation alleged to have been violated. If the motivation for allowing legislation to be challenged as such is to provide the predictability needed to plan future trade, then challenges to discretionary laws are essential tools to achieve this end. When the Agreement clearly requires a particular course of action, a law that authorizes the administrative authorities to behave differently should be regarded as inconsistent with the Agreement and a violation as such.

Unfortunately, the ruling in the case discussed here runs counter to the sentiments expressed by the Panel in US-Section 301. The AB appears to adhere still to a rigid distinction between mandatory and discretionary law. Its ruling reinforces the proposition that 'as such' claims will be held to a higher standard than claims against individual measures $;^{21}$ that an 'as such' claim can only succeed if it is firmly established that the law or norm being challenged requires a particular behavior contrary to WTO obligations; and that the preconditions for a successful 'as such' challenge are independent of the nature or scope of the obligation alleged to have been violated. It is now clear that the $\mathrm{AB}$ meant to say in US-CorrosionResistant Steel only that a law that appears to be written in a discretionary manner

21 The AB's outlook on the seriousness of 'as such' claims can be seen in the following quote from its report:

'[A]s such' challenges against a Member's measures in WTO dispute settlement proceedings are serious challenges. By definition, an 'as such' claim challenges laws, regulations, or other instruments of a Member that have general and prospective application, asserting that a Member's conduct - not only in a particular instance that has occurred, but in future situations as well - will necessarily be inconsistent with that Member's WTO obligations. In essence, complaining parties bringing 'as such' challenges seek to prevent Members ex ante from engaging in certain conduct. The implications of such challenges are obviously more far-reaching than 'as applied' claims. (para. 172) 
might nonetheless be de facto mandatory in nature. ${ }^{22}$ But if the law or regulation in question does not mandate actions that are inconsistent with WTO obligations, there can be no violation of the Agreement, irrespective of the type of obligation allegedly violated. ${ }^{23}$ For the reasons indicated earlier, we regret this rigid approach. ${ }^{24}$

Howse and Staiger were correct about one point: The AB will henceforth consider substance (and not just form) by allowing a complainant to argue that an apparently discretionary law or practice actually requires certain actions de facto. But the ruling in US-OCTG from Argentina makes clear that the evidentiary burden for this will be great. Evidently, it will not suffice to provide evidence that a certain pattern of behavior has been followed in more than 200 cases. Nor was the AB persuaded by the inability of the United States to provide a single counterexample to Argentina's claims that the three scenarios are jointly determinative. And the AB did not care that the SPB had been written by the executive authority itself to express how it intended to rely primarily, if not entirely, on the three scenarios. The $\mathrm{AB}$ considered none of this to be proof of a mandated action, because, after all, the repeated behavior by the USDOC could be coincidental and the absence of a counterexample could reflect only that appropriate circumstances had yet to arise. ${ }^{25}$

22 In the case discussed here, the $\mathrm{AB}$ considered the relevant question to be whether the three scenarios outlined in the SPB are in fact conclusive or only indicative for the USDOC in reaching a positive decision on likely continuation or recurrence of dumping. According to the $\mathrm{AB}$, if a legal instrument does not expressis verbis indicate that a particular approach is required, the mandatory nature of the approach may nevertheless be established by the way the law operates and is implemented by the executive authority. But there is nothing revolutionary about that: in so doing the $\mathrm{AB}$ merely confirmed the generally accepted and oft-repeated notion that a Member's domestic laws are matters of fact and that the meaning of such laws cannot be established simply by looking at the legislative text. One should also examine the application and interpretation given to the text by the executive authorities and the courts. See AB Report, US-Carbon Steel, para. 157.

23 In contrast to the Panel's response in US-Section 301, the AB in US-OCTG from Argentina did not examine whether Article 11.3 of the AD Agreement rules out any behavior in a sunset review that the SPB allows. Evidently, the AB did not consider this to be germane to the decision. It would not consider the SPB to be in violation of the AD Agreement just because it allows the USDOC the discretion in a sunset review to act in a manner contrary to the United States's international obligations.

24 The AB stresses this point in US-Carbon Steel:

The party asserting that another party's municipal law, as such, is inconsistent with relevant treaty obligations bears the burden of introducing evidence as to the scope and meaning of such law to substantiate that assertion. Such evidence will typically be produced in the form of the text of the relevant legislation or legal instruments, which may be supported, as appropriate, by evidence of the consistent application of such laws, the pronouncements of domestic courts on the meaning of such laws, the opinions of legal experts and the writings of recognized scholars. The nature and extent of the evidence required to satisfy the burden of proof will vary from case to case.' (para. 157)

25 It is interesting to compare this approach with the one followed in respect of the waiver provisions in this same case, and the one adopted in the US-Zeroing $(E C)$ case. In both cases, the fact that the US was unable to come up with one example to rebut the allegation made was considered highly instructive. See 
In rejecting Argentina's 'statistical evidence' (which, in this case, was $100 \%$ consistent with its hypothesis, not the usual $95 \%$ or $99 \%$ normally applied to statistical inference), the $\mathrm{AB}$ insisted on seeing examples of cases in which a USDOC ruling had corresponded to the indications of the three scenarios despite the existence of convincing evidence that the opposite outcome on dumping was likely. Moreover, Argentina would have had to show that the authorities had ignored the convincing evidence in deference to the applicability of one of the three scenarios. With this standard of evidence, there is not much chance for a claimant alleging an 'as such' violation to prevail except when the law or administrative measure expresses a clear mandate. The distinction between form and substance that the $\mathrm{AB}$ had identified in US-Corrosion-Resistant Steel apparently is one that makes little difference in practice: A Member will be able to challenge a measure that appears to be discretionary, but the challenge is most unlikely to succeed.

\subsection{Factors to be evaluated in a likelihood-of-injury determination}

Article 11.3 of the $\mathrm{AD}$ Agreement requires, inter alia, that the investigating authorities examine in a sunset review whether any dumping that is deemed likely to continue or recur following the termination of a duty order is likely to lead to a continuation or recurrence of injury to the domestic industry. The dispute in US-OCTG from Argentina addressed the question to the AB of what economic factors ought to be considered in such an examination, and, in particular, whether the disciplines imposed by Article 3 on the investigating authorities concerning injury determination in an initial investigation of dumping apply also to sunset reviews. The $\mathrm{AB}$ answered this question clearly and simply in the negative. According to the $\mathrm{AB}$, the absence of any explicit cross-reference in Article 11.3 to the disciplines included in Article 3 and the oft-cited difference in the nature and purpose of an original investigation versus a sunset review are enough to resolve the issue in favor of a minimalist interpretation of the disciplines imposed by Article 11.3.

In the next section of this paper, we will argue that the obligation to conduct an examination of likely continuation or recurrence of injury asks quite a lot of the investigating authorities from an economic point of view. The authorities must address a counterfactual question of what industry outcomes would likely result from the removal of an antidumping-duty order, considering the likely pricing behavior by foreign firms and the associated strategic response by the domestic industry. In order to address this question rigorously and nonmechanistically, the authorities cannot avoid a rather detailed economic analysis. Here we shall argue

AB Report, US-OCTG from Argentina, para. 233 and Panel Report, US-Zeroing (EC), para. 7.103, and the latter referred to with approval in the $\mathrm{AB}$ report, US-Zeroing (EC), para. 201. 
on legal grounds that a proper contextual interpretation of the term 'injury' in Article 11.3 should have led the $A B$ to decide this aspect of the dispute differently and that, in fact, the types of disciplines imposed by Article 3 should apply to sunset reviews as well.

Argentina argued that the term 'injury' should be interpreted in a consistent manner throughout the Agreement, be it as a condition for imposing an antidumping duty or as a condition for failing to terminate a duty order after five years. Argentina pointed to footnote 9 to the heading of Article 3, which states, 'Under this Agreement the term 'injury' shall, unless otherwise specified, be taken to mean material injury to a domestic industry, threat of material injury to a domestic industry or material retardation of the establishment of such an industry and shall be interpreted in accordance with the provisions of this Article' (emphasis added). The AB accepted Argentina's argument that the injury referenced in Article 11.3 is 'material injury to a domestic industry, threat of material injury to a domestic industry or material retardation of the establishment of such an industry', but somehow overlooked the last phrase of the footnote when ruling that Article 3 does not set forth any definition of the term injury that applies to a determination of injury.

We see no basis for the $\mathrm{AB}$ ruling that Article 3 applies only to the determination of existing injury in an initial investigation, and not to the determination of likely continuation or recurrence of injury in a sunset review. After all, footnote 9 makes clear that, wherever the term 'injury' appears in the Agreement, unless otherwise specified, it must be interpreted in accordance with the provisions of Article 3. Article 11 contains no explicit statement that a different interpretation of 'injury' is required for sunset reviews. Accordingly, the provisions of Article 3 for determining injury ought to apply mutatis mutandis to the examination of injury required by Article 11 .

According to the $\mathrm{AB}$, the different nature and purpose of injury determinations in original investigations and sunset reviews justifies the possible use of different approaches in the two types of investigation. The AB has made similar statements about the different nature of sunset reviews and original investigations in other cases as well, but it has failed to explain why this difference implies a different set of disciplines and why it justifies reading out of the Agreement the last part of footnote 9. Of course, sunset reviews are different from original investigations; in an original investigation the relevant question is the existence or threat of injury, whereas in a sunset review it is the likely continuation or recurrence of injury. But the reason for an injury test presumably is the same in each case; namely, so as not to restrict trade unnecessarily when the actions of the foreign firms do not threaten or impose harm to domestic interests. Why would the signatories have meant this test to be weaker, and subject to less discipline, in a sunset review than in an initial investigation? If anything, the test in a sunset review should be stricter, and the disciplines greater, considering that Article 11.3 sets a presumption that the 
duty order shall be terminated unless a review finds circumstances to justify its continuation. $^{26}$

In fact, the injury determination required in a sunset review may not be so different from that in an initial investigation of dumping. In an initial investigation, the authorities should first examine the existence of injury. But, where injury does not exist, they must then examine the threat of injury. In doing so, they must forecast future conditions in the industry, just as they must do in a sunset review. Article 3.7 lists factors that must be considered by the authorities when forecasting the future in assessing threat of injury. Why would they not need to look at a similar set of factors when forecasting the future following an assumed termination of the duty order? Moreover, as the Panel in Mexico-Corn Syrup (para. 7.132) correctly pointed out, the factors listed in Article 3.7 relate specifically to the likelihood of increased imports and not the resulting impact of the subject imports on the domestic industry. Their ruling implies that an examination of only the factors cited in Article 3.7 would not suffice for an investigating authority to determine that a threat of injury exists. Rather, the authority remains obligated to consider the impact of dumped imports on the domestic industry in accordance with the requirements of Article 3.4. By this reasoning, if the disciplines of Article 3.4 apply to an investigation of the threat of future injury in an initial investigation, they ought to apply as well to an investigation of the likelihood of future injury in a sunset review.

It is difficult to see how an investigating authority could fulfill its obligation from Article 11.3 to review the likelihood of continuation and recurrence of dumping and injury without obeying the disciplines of Article 3. Article 3 requires the investigating authority to examine the volume of dumped imports and the effect of these imports on the prices of competing domestic goods. Then it requires the authority to examine the impact of the dumped imports on domestic producers by evaluating all relevant factors that bear on the state of the industry. The list of factors in Article 3.4 includes basic measures of the health of the industry, such as sales, profits, productivity, market share, etc. Surely, the same set of factors is relevant for forecasting the health of the industry following the removal of a duty order. And when the AB states that some of the factors listed in Article 3.4 may not be so relevant in particular sunset reviews, depending on circumstances, this is no different from the fact that some factors may be less relevant than others in an initial investigation of dumping. For example, industry wages and

26 The AB in US-Carbon Steel has accepted that, in sunset reviews, the termination of the duty should be considered 'the rule' and its continuation 'the exception'. In that decision, dealing with the sunset review provision in the SCM Agreement (which is identical to that in the AD Agreement, mutatis mutandis), it wrote:

An automatic time-bound termination of countervailing duties that have been in place for five years from the original investigation or a subsequent comprehensive review is at the heart of this provision. Termination of a countervailing duty is the rule and its continuation is the exception. (para. 88) 
employment may not be such important factors in determining the health of a highly capital-intensive industry. Then this factor will not figure prominently in an initial investigation, even though Article 3.4 requires that it be considered. Why would not the same be true of a sunset review?

We see the role of Article 3 as being to ensure transparency and to impose discipline on Members that wish to introduce antidumping duties. The provisions require the investigating authority in the importing country to consider all relevant economic factors before it concludes that there has been injury and imposes measures that impede trade. We see nothing in the text of the Agreement, or in the economics of the situation, to suggest that such transparency and discipline is less important in a review of a longstanding order than in an original investigation of alleged dumping. If anything, we believe the opposite is true.

\subsection{Permissibility of cumulation in sunset reviews}

The $\mathrm{AB}$ ruled that the rationale for allowing cumulation in original investigations is 'equally applicable' to determinations of likelihood of injury following the removal of an antidumping duty. Although we have our doubts about the use of cumulation in general, the $\mathrm{AD}$ Agreement is clear on the permissibility of this practice in original investigations of injury. We can see no basis in the text for concluding that the Members meant for a different practice to apply in regard to cumulation in assessing likelihood of continued or recurring injury. ${ }^{27}$

However, it would seem that if the rationale for allowing cumulation is equally applicable to sunset reviews, the disciplines imposed by the Agreement to prevent abuse of this procedure ought to apply as well. The AB argues differently, however, focusing not on the rationale of the rule, but on a narrow, textual analysis. The AB points out that the text of Article 3.3, which sets forth such disciplines, refers to their applicability to antidumping 'investigations', and not to antidumping 'reviews'. But why would the term 'investigations' not be broad enough to cover both the original investigation of a claim of dumping and a subsequent review of the effects of removal of an antidumping order? The narrowness of the interpretation seems especially misplaced in light of the $\mathrm{AB}$ ruling that the same rationale for allowing cumulation applies in both cases.

One might well ask, why would the drafters of the Agreement have wished to impose disciplines on the practice of cumulation in original investigations, but not in reviews if, as the $\mathrm{AB}$ argues, the question in both cases is the same?

27 We note, however, that an economic argument similar to that made by Howse and Staiger (2006: 43-46) can be offered in favor of different procedures in the two types of determinations. Howse and Staiger argued that determining likelihood of continued or renewed dumping on an order-wide basis introduces a free-rider problem among the countries named in a dumping order, since each has limited ability to change its behavior in such a way as to rid itself of the order. Under a company-specific basis for determining likelihood of continued or renewed dumping, by contrast, each firm potentially can reap the rewards of its own 'good' behavior. Similarly, the use of cumulation in the determination of likelihood of injury from continued or renewed dumping may dampen the incentive for firms and countries to refrain from dumping that is likely to cause new injury. 
In each case, the question concerns the impact of dumped imports on the domestic industry. Surely, if the disciplines on the practice of cumulation help us to assess accurately whether the dumped imports contributed to the existing state of an industry, they would also help us to assess accurately whether prospective dumped imports would contribute to the future state of the industry. But the AB does not even pose this question, let alone provide a reasoned answer.

The $\mathrm{AB}$ tries to reassure us that the inapplicability of the disciplines of Article 3.4 to sunset reviews does not mean that 'anything goes'. In such a review, the authority's decision to use cumulation still must qualify as a 'rigorous examination' leading to a 'reasoned conclusion' supported by 'positive evidence' and a 'sufficient factual basis' (para. 302). Apparently, the AB feels that these general terms are sufficient to impose the disciplines needed to avoid abuse. But if that is so, why did the Members feel the need to include the disciplines it did in Article 3.3 ? Shouldn't the general terms have been sufficient there as well ? And besides preventing abuse, the listing of permissible procedures in a review helps to remove the uncertainty that parties face as to how they will be treated in a dumping investigation. Surely this rationale applies as much to sunset reviews as it does to initial investigations.

Alas, it is not even true that the $\mathrm{AB}$ remains faithful to the text in this part of its decision. First, it denies the applicability of disciplines for cumulation in a sunset review, because such disciplines are not to be found in Article 11.3. Then, it asserts the more general discipline imposed by the requirement for a 'rigorous examination', a 'reasoned conclusion', and a 'sufficient factual basis'. However, not only are these terms absent from Article 11.3, in fact they appear nowhere in the $\mathrm{AD}$ Agreement.

\section{The economics of sunset reviews}

Economic analysis of the sunset review provisions of the $\mathrm{AD}$ Agreement is complicated by the fact that the agreement as a whole lacks a coherent economic justification and interpretation. Several previous authors in this series have argued-and we concur-that the purpose and objectives of the condemnation of dumping and the provisions for antidumping duties are far from clear, as they do not seem to address any international externality or to curb noncooperative governmental behavior. ${ }^{28}$ Without a clear understanding of why antidumping duties are tolerated by the international trading system in the first place, it is difficult to discuss the conditions under which they ought to be terminated.

There is no point in our rehearsing yet again the reasons why economists find fault with the AD Agreement as a whole. This issue has been discussed in great

28 See, for example, Janow and Staiger (2003), Howse and Neven (2003), and Horn and Mavroidis (2006). 
depth elsewhere. ${ }^{29}$ Instead, we will suspend our disbelief and take at face value that antidumping duties have some legitimate role to play in the world trading system and that the purpose of the sunset review is to determine whether "expiry of the duty would be likely to lead to continuation or recurrence of dumping and injury'.

The $\mathrm{AB}$ has interpreted the words 'review' and 'determine' in Article 11.3 as requiring authorities in a sunset review to come to a 'reasoned conclusion on the basis of information gathered as part of a process of reconsideration and examination'. ${ }^{30}$ The review cannot be mechanistic or formulaic. But it rejected Argentina's argument that the three scenarios of the SPB are determinative in US sunset reviews based on the historical record of findings in past reviews. Be that as it may, it is clear to us that the United States has not fulfilled its obligation to reach a 'reasoned conclusion' in this or any other sunset review.

Our claim is based on the failure of the United States to recognize, either in the wording of the SPB or in its current or past practice of sunset reviews, the nature of the questions that are posed by Article 11.3 of the AD Agreement. The questions are counterfactual: ${ }^{31}$ What industry conditions are likely to prevail in the event that the duty order is lifted? Would dumping continue or resume in the absence of an antidumping-duty order? If so, would the dumped imports result in continued or recurring injury to the domestic industry?

To answer these questions requires, as Howse and Staiger (2006: 47) have pointed out, 'an understanding of two things: (i) what conditions led to dumping in the first place; and (ii) whether those conditions have changed in a way that removes the original reason for dumping'. As they further argue, 'neither of these two elements appears to play any real role in the USDOC's methodology for determining likelihood'. Ergo, the US practice as such (as described in the SPB or inferred from its repeated actions) and the US practice in this instance cannot have fulfilled the country's obligation to provide a reasoned conclusion to the counterfactual questions posed by Article 11.3.

A proper sunset review would begin with a description and analysis of competitive conditions in the industry in question. This analysis would address, inter alia, the reasons that dumping took place in the first place. Was there excess

29 See, for example, Boltuck and Litan (1991).

30 US-Corrosion-Resistant Steel, para. 111.

31 The United States acknowledged the counterfactual nature of the sunset review exercise in the Statement of Administrative Action that accompanied the implementing legislation. In Uruguay Round Trade Agreements, Texts of Agreements, Implementing Bill, Statement of Administrative Action, and Required Supporting Statements, H. Doc. 103-316, vol. 1, 103 Cong. 2 sess. (GPO, 1994: 884), it is written that 'under the likelihood standard, the Commission will engage in a counterfactual analysis: it must decide the likely impact in the reasonably foreseeable future of an important change in the status quo ... the revocation or termination of a proceeding and the elimination of its restraining effects on volumes and prices of imports'. 
capacity in the industry that led foreign firms to price below their long-run average cost? Were international markets segmented and foreign firms attempting to gain additional oligopoly profits by practicing price discrimination? Did exchangerate movements together with 'pricing-to-market' lead to different prices in two markets? Did the dumping have predatory intent? Although the AD Agreement does not in any way limit Members' rights to impose antidumping duties according to the motivation for this pricing behavior, an understanding of the reasons for the dumping is essential for properly addressing the issue of whether dumping and injury are likely to continue or recur if a duty order is allowed to expire.

Put differently, the investigating authorities need to develop a 'model' of the industry in question. ${ }^{32}$ This model need not be a formal one, expressed in equations and complete with econometric estimates of important parameter values. Where feasible, such an econometric model could be valuable in assessing how changes in industry conditions are likely to affect pricing strategies and industry outcomes. But data limitations and time pressures will sometimes prevent investigating authority from conducting formal economic analysis. In some cases, the best feasible examination of the issue may involve the use of a more informal model - basically, a consistent 'story' about how the industry operates - in order to allow consideration of the relevant counterfactual issues. Certainly, the same model should not apply in every case; competitive conditions and market structure vary across industries, as do the importance of spare capacity, or exchange-rate shocks, and other factors that play a role in firms' pricing strategies. But without a conceptual model of the industry in question, any sunset review is bound to be formulaic and mechanical.

Once the investigating authorities have described the competitive conditions in the industry and identified the motive for the foreign firms' initial dumping, the next step in a proper examination of the likelihood issue requires them to consider how conditions in the industry have changed and to forecast what would be firms' pricing strategies under the new conditions and the assumed removal of the antidumping-duty order. If, for example, the root cause of the initial dumping is deemed to have been cyclical factors that created excess capacity, a relevant question is whether the conditions of spare capacity persist in the industry. If, alternatively, the initial dumping was associated with exchange-rate misalignment, the prevailing exchange values might be relevant. The counterfactual analysis that is mandated by the text of Article 11.3 of the AD Agreement can be formal or informal, depending on the available data and information. If, for example,

32 Boltuck and Kaplan (1998) make a similar argument in their template for the conduct of sunset reviews written before any such reviews had taken place. In particular, they advocate a counterfactual analysis that combines the use of a family of comparative static economic simulation models with more informal methods of industry analysis. They note, as we do, that conditions of competition will vary across different markets, and so a 'one size fits all' approach to the review process cannot be appropriate. 
it is possible to describe industry conditions in a formal model with econometric estimates of key demand and cost parameters, then the likelihood question can be addressed by solving the model 'out of sample' using prevailing values of exogenous variables and an assumed change in the duty order applicable to subject imports. ${ }^{33}$ If this is not possible due to data and time limitations, then an alternative would be to perform the necessary counterfactual experiments conceptually and possibly with the aid of industry experts. In either case, the goal should be to use the best available understanding of how the industry operates to address what outcomes are most likely in the event that the antidumping-duty order is terminated.

We would argue further that one element of the competitive condition in the industry is bound to have changed between the time of the initial investigation of dumping and the sunset review. Namely, at the time of the initial investigation, the foreign firms that engaged in the suspect pricing strategy may have been uncertain about whether their strategy constituted 'dumping' as legally defined and were certainly uncertain about whether their practice would lead to the filing of petitions of dumping and injury by the domestic industry. The firms presumably will have decided that the extra profits they could earn by pursuing a pricing strategy that might be challenged and then construed as 'dumping' outweighed the expected costs associated with the imposition of an antidumping-duty order. However, by the time of the sunset review, much or all of this uncertainty will have been resolved. If the duty order is revoked and these firms return to their prior pricing strategy, they can be reasonably sure that the practice will not go unnoticed. And, if challenged, they expect a similar finding to the first outcome unless industry conditions have changed substantially. It stands to reason that the temptation to 'dump' will be less, subsequent to the removal of a duty order, than it was before the initial investigation.

An analogy may help to clarify this point. Consider a criminal who has been arrested and convicted of theft. Before committing the original crime, the individual will have compared the perceived gains from the illegal activity with the expected cost of any ensuing punishment, taking account of the likelihood of being caught. Now suppose the thief is released from prison on parole. He may be unreformed in terms of social conscience and see the profits from thievery much as before. However, he will know that he is being monitored and that the probability of 'getting away with it' has diminished. The likelihood that he will resume a life of crime in the parole state, while not zero, normally will be reduced. The same is true for a firm that engages in dumping: it may see the profitability of this pricing strategy as being similar to what it was initially, but now choose to refrain in light of the anticipation of closer scrutiny.

33 See also Keck, Malashevich, and Gray (2006), who advocate the use of simulation methods to address the prospective determination that is required in the sunset review process. 
It is interesting to note that our proposed analysis for sunset reviews fits comfortably with recent proposals made by Canada (TN/RL/GEN61) and Japan (TN/RL/GEN/104). The Canadian proposal, for example, provides the following list of factors that ought to be examined in sunset review of likely injury:

(a) the likely volume of dumped imports if the duty is allowed to expire, and, in particular, whether there is likely to be a significant increase in the volume of the dumped imports, either in absolute terms or relative to the production or consumption of the like product;

(b) the likely prices of the dumped imports if the measure is allowed to expire and their effect on the prices of the like product, and, in particular, whether the dumped imports are likely to significantly undercut the prices of the like product, or lead to price depression or price suppression;

(c) the likely performance of the domestic industry and of the foreign industry, taking into consideration their recent performances, including trends in production, capacity utilization, the potential for foreign producers to extend production to facilities currently used to produce other products, the employment levels, prices, sales, inventories, market share, exports and profits;

(d) the likely impact of the dumped imports on the domestic industry if the measure is allowed to expire, having regard to all relevant economic factors and indices, including any potential decline in output, sales, market share, profits, productivity, return on investments or utilization of production capacity, and any potential negative effects on cash flow, inventories, employment, wages, growth, including efforts to produce a derivative or more advanced version of the like product, or the ability to raise capital;

(e) changes in market conditions in the economy of the Member and internationally, including changes in the supply of and demand for the imports, as well as any changes in trends and in sources of imports into the Member; and

(f) evidence of the imposition of anti-dumping or countervailing duties by other Members in respect of like or similar products, and evidence that such duties are likely to cause a diversion of imports into the Member.

It should be clear that an investigating authority would need to look at a list of factors such as those contained in the Canadian proposal in order to address the counterfactual analysis about likely continuation or recurrence of dumping and injury that is mandated by Article 11.3. The incorporation of a list of factors such as this one into the AD Agreement would certainly clarify the required elements of a sunset review. But, we would argue that the $\mathrm{AB}$ should have no difficulty in interpreting the agreement as currently worded in a manner that recognizes the economic issues at stake. 


\section{Conclusions}

This case is one of several that deals with sunset reviews of antidumpingduty orders. By its cumulative rulings, the Appellate Body has made clear that it does not expect very much from these reviews. Countries are free to assess the likelihood of continuation or recurrence of dumping without much regard for prevailing conditions in the industry, to assess the likelihood of continuation or recurrence of injury without any of the disciplines imposed on original dumping investigations, and to use whatever methods and procedures they see fit, provided that they can somehow claim to have reached a reasoned conclusion based on information gathered for the purpose. They can even rely repeatedly on a formulaic approach, provided that the other Members cannot show beyond a reasonable doubt that the approach has led to indefensible findings in earlier cases. In short, the $\mathrm{AB}$ has ensured that the sunset review process agreed to in the Uruguay Round has no teeth. Considering that sunset reviews were introduced to enforce a presumption that antidumping-duty orders ought to expire after five years except in particular and unusual circumstances, we cannot see this as a desirable or acceptable outcome of the jurisprudence.

Among the most important shortcomings of the AB ruling in US-OCTG from Argentina are two. First, the $\mathrm{AB}$ has reasserted a rigid distinction between mandatory and discretionary law. A law or executive order that requires an administrative authority to behave in a way that is inconsistent with a country's WTO obligations can be challenged 'as such' before the organization's dispute settlement bodies, and the complainant need only establish the existence of a requirement and its inconsistency with the agreement. A law or executive order that allows for behavior that is inconsistent with the agreement also can be challenged, but the standards for success are extraordinarily high. The complainant must then establish that the law or practice in fact has required the authorities to make decisions that run counter to WTO obligations; i.e., that the discretion to act legally or illegally in fact did not exist, and that such illegal action by the executive authority in the past was in fact mandated by the law or practice in question. This ruling is unfortunate, because it diminishes Members' incentives to challenge laws and practices as such, and forces them to wait for particular, disputable applications. As-such challenges could play a useful role in the trading system in helping to provide a stable and predictable environment for trade and in thwarting Members' efforts to continue illegal actions by a series of small changes in law with little change in practice.

Second, the $\mathrm{AB}$ failed to recognize the purpose and objectives of sunset reviews by failing to impose any discipline on their conduct. Surely the reviews have a purpose similar to that of original investigations - to ensure that duty orders are not imposed when their absence would not generate harm to an import-competing industry. Inasmuch as the Members saw fit to impose many disciplines on the conduct of original investigations in order to ensure that duty orders were not 
introduced when injury-causing dumping had not taken place, it is inconceivable that they could not have meant an analogous set of disciplines to apply in sunset reviews; all the more so because the reviews were presumptively intended to rid the system of obsolete orders.

It would have been possible for the $\mathrm{AB}$ to interpret the existing treaty language differently from what it has done. However, given the history of jurisprudence that has now accumulated, we would advocate an addendum by the Members that would clarify their intention to create a meaningful and disciplined sunset review process.

\section{References}

Boltuck, R. D. and R. E. Litan (eds) (1991), Down in the Dumps: Administration of the Unfair Trade Laws, Washington, DC: The Brookings Institution.

Boltuck R. D. and S. T. Kaplan (1999), ‘An Economic Approach to ITC Sunset Reviews’, in R. Lawrence (ed.), Brookings Trade Forum 1998, Washington, DC: The Brookings Institution.

Horn, H. and P. C. Mavroidis (2006), 'European Community - Antidumping Duties on Malleable Cast Iron Tube or Pipe Fittings from Brazil', in H. Horn and P. C. Mavroidis (eds), The American Law Institute Reporters' Studies - The WTO Case Law of 2003, Cambridge: Cambridge University Press.

Howse, R. and D. J. Neven (2003), 'Argentina-Definitive Anti-dumping Measures on Imports of Ceramic Floor Tiles from Italy', in H. Horn and P. C. Mavroidis (eds), The American Law Institute Reporters' Studies - The WTO Case Law of 2001, Cambridge: Cambridge University Press.

Howse, R. and R. W. Staiger (2006), 'United States - Sunset Review of Anti-Dumping Duties on Corrosion-Resistant Carbon Steel Flat Products from Japan: A Legal and Economic Analysis of the Appellate Body Ruling', in H. Horn and P. C. Mavroidis (eds), The American Law Institute Reporters' Studies - The WTO Case Law of 2003, Cambridge: Cambridge University Press.

Janow, M. E. and R. W. Staiger (2003), 'European Communities - Anti-Dumping Duties on Imports of Cotton-Type Bed Linen from India', in H. Horn and P. C. Mavroidis (eds), The American Law Institute Reporters' Studies - The WTO Case Law of 2001, Cambridge: Cambridge University Press.

Keck, A., B. Malashevich, and I. Gray (2006), 'A “Probabilistic” Approach to the Use of Econometric Models in Sunset Reviews', Staff Working Paper ERSD-2006-01, World Trade Organization Economic Research and Statistics Division, Geneva, Switzerland. 